\title{
Regerach Article: Study on genetic divergence in boro rice (Oryza sativa L.) germplasm
}

\section{G. RAJENDRA PRASAD, K.V. RADHA KRISHNA AND L.V. SUBBA RAO}

Article Chronicle: Received : 15.07.2017; Accepted : 30.07.2017

KeY Words: Cluster analysis, Genetic divergence, Hybridization, Rice

Author for correspondence :

\section{K. RAJENDRA PRASAD}

Department of Genetics and Plant Breeding, College of Agriculture, Professor Jayashankar Telangana State Agricultural University, Rajendranagar, HYDERABAD (TELANGANA) INDIA See end of the article for authors' affiliations
SUMMARY : Genetic diversity among fifty genotypes of boro Rice from Directorate of Rice Research, India was evaluated using Mahalanobis $\mathrm{D}^{2}$ statistic. The experimental materials were evaluated during Rabi 2013-14, Directorate of Rice Research Farm, ICRISAT Campus, Patancheru, Hyderabad. Situated at $17.53^{\circ} \mathrm{N}$ latitude, $78.27^{\circ} \mathrm{E}$ longitude and altitude of $545 \mathrm{~m}$ above mean sea level. Based on 10 quantitative characters which includes days to 50\% Flowering, Plant Height (cm),Number of tillers/ plant, Number of productive tillers/plant,Panicle length $(\mathrm{cm})$, Number of filled grains/panicle, Number of unfilled grains/ panicle, Days to maturity, Grain yield/plant $(\mathrm{g})$ and 1000 grain weight $(\mathrm{g})$. These genotypes were grouped into 10 clusters. Out of Ten clusters, cluster I was the largest comprising of 18 genotypes followed by clusters II with 15 genotypes, cluster IV with 10 genotypes, and cluster III, V, VI, VII, VIII, IX, X with one genotype each.The clusters III,V, VI,VII,VIII, IX, X were represented by single genotype indicating high degree of heterogeneity among the genotypes.Clusters VIII, IX, and X exhibited high values for most of the characters. The intra cluster distance was maximum $\left(\mathrm{D}^{2}=38.68\right)$ in cluster IV. The maximum inter cluster distance $\left(\mathrm{D}^{2}=387.67\right)$ was recorded between clusters VI and VIII. Cluster X recorded highest mean value for grain yield per plant and lowest mean value for panicle length $(\mathrm{cm})$. Days to fifty per cent flowering $(41.22 \%)$ followed by number of filled grains per panicle $(30.61 \%)$ contributed maximum to total divergence.Based on the inter cluster distances, a hybridization between the genotypes (IC-70855) of cluster VI and cluster VIII (IC-145639), cluster VIII (IC-145639) and cluster X (IC-86143), cluster III (IC-67935) with cluster V (IC-145633), is suggested to generate promising segregants for grain yield would produce encouraging results.

How to cite this article : Prasad, K. Rajendra, Krishna, K.V. Radha and Rao, L.V. Subba (2017). Study on genetic divergence in boro rice (Oryza sativa L.) germplasm. Agric. Update, 12(TECHSEAR-5) : 1339-1344; DOI: 10.15740/HAS/AU/12.TECHSEAR(5)2017/1339-1344. 